\title{
Pembangunan Karakter Tokoh Utama Melalui Dialog Pada Film Musikal "The Greatest Showman"
}

\author{
Alifia Nuralita Rezqiana \\ Siti Maemunah \\ Endang Mulyaningsih \\ Jurusan Film \& Televisi, Fakultas Seni Media Rekam, Institut Seni Indonesia Yogyakarta \\ Jl. Parangtritis km. 6.5 Yogyakarta Telp. (0274) 381047
}

\begin{abstract}
The Greatest Showman is a phenomenal musical film that tells a story about an American showman named P. T. Barnum. This film managed to get lot of awards and inspired a lot of people around the world. On the other hand, this film also drew lot of critical criticisms from the film critics. This study aims to analysed the development of the main character through dialogue in musical film The Greatest Showman.

The qualitative method with descriptive approach will be used in this study. The data examined in this study are the whole scenes breakdown of the film. This study will be focused on analysing the main character development through dialogue and song lyrics of the film while still considering the visual elements. Dialogues and song lyrics will be analysed by describing the dialogue's function, structure, style, and the dialogue' s integration with other cinematic elements.

The results of this study showed that dialogue has the capability to describe the physiological, sociological and psychological dimensions of the main character. The development of the main character in The Greatest Showman is shown more through the dialogue than visual elements. The result showed there are lots of character dimensions that are only appear through dialogue. Nevertheless, there are also few character dimensions that only appear through visual elements of the film.
\end{abstract}

Keywords: Character Development, Main Character, Dialogue, Musical Film, The Greatest Showman

\begin{abstract}
Abstrak
Film The Greatest Showman merupakan film musikal fenomenal yang menceritakan tentang perjalanan karier seorang tokoh seniman pertunjukan bernama P. T. Barnum. Film ini berhasil mendapatkan berbagai penghargaan dan digemari oleh masyarakat, namun juga menuai kritik pedas dari para kritikus film. Penelitian ini bertujuan untuk menganalisis pembangunan karakter tokoh utama melalui dialog pada film musikal The Greatest Showman.

Analisis dilakukan menggunakan metode kualitatif dengan pendekatan deskriptif. Data yang dikaji dalam penelitian ini adalah seluruh breakdown scene Film The Greatest Showman. Analisis pembangunan karakter akan dilihat melalui unsur audio yang terdiri dari dialog dan lirik lagu dengan tetap memperhatikan unsur visual di dalamnya. Dialog dan lirik lagu akan dianalisis dengan cara menguraikan fungsi dialog, struktur dialog, gaya dialog dan integrasi dialog dengan unsur sinematik lain.

Hasil penelitian menunjukkan bahwa unsur-unsur dialog mampu menunjukkan dimensi fisiologis, sosiologis dan psikologis tokoh utama. Pembangunan karakter tokoh utama pada Film The Greatest Showman lebih banyak ditunjukkan melalui dialog daripada visual. Dialog mendominasi pembangunan dimensi karakter sosiologis dan psikologis. Meskipun demikian, terdapat beberapa dimensi karakter yang hanya muncul melalui unsur visual, terutama pada dimensi fisiologis.
\end{abstract}

Kata kunci : Pembangunan Karakter, Tokoh Utama, Dialog, Film Musikal, The Greatest Showman. 


\section{Alifia Nuralita Rezqiana, Siti Maemunah, Endang Mulyaningsih}

Pembangunan Karakter Tokoh Utama melalui Dialog pada Film Musikal "The Greatest Showman"

\section{Pendahuluan}

Film merupakan sebuah karya seni yang diwujudkan melalui media audio visual. Sebagai sebuah media ekspresi, film digunakan untuk menyampaikan cerita dan gagasan melalui visualisasi yang nyata dengan menggabungkan berbagai elemen seni di dalamnya. Musikal menjadi salah satu genre film yang paling lama dan paling populer dengan kehadiran komponen lagu dan tari di dalam film (Giannetti 2014, 215).

Film musikal terus diproduksi dari tahun ke tahun dan hingga saat ini masih sangat diminati oleh para penikmat film. Dalam 40 tahun terakhir, film musikal membuktikan eksistensinya dengan berbagai pencapaian, baik dari segi penghargaan di festival film bergengsi maupun dari segi penjualan yang sukses besar. Tahun 2017 lalu, bioskop Indonesia cukup ramai dengan kehadiran berbagai judul film musikal, di antaranya adalah film Naura dan Genk Juara, film Beauty and The Beast (live-action), Pitch Perfect 3, film animasi Coco dan film The Greatest Showman.

Film musikal The Greatest Showman menjadi film yang istimewa karena mampu bertahan hingga lebih dari 8 minggu di bioskop Indonesia. Film ini tayang perdana pada tanggal 29 Desember 2017. Hingga akhir bulan Februari 2018 film ini masih ditayangkan di beberapa bioskop tanah air. Hal ini membuktikan antusias dan apresiasi masyarakat Indonesia yang begitu besar terhadap film The Greatest Showman.

Tidak lama setelah tayang perdana, beberapa kritikus mulai memberikan ulasan yang cukup pedas terhadap film ini (TheVintageNews.com 2019). Terlepas dari kritik pedas yang banyak beredar di berbagai media, film musikal The Greatest Showman telah memenangkan 18 dari 55 nominasi penghargaan (per 12 Desember 2019).

Sebuah film musikal tentu saja tidak akan lepas dari unsur lagu. Salah satu hal yang menarik dari film musikal adalah dialog yang dinyanyikan oleh para pemeran. Film The Greatest Showman memiliki beberapa scene dengan dialog yang dikemas dalam bentuk lagu. Dialog berupa lagu pada scene tersebut menjadi istimewa karena di dalam adegan yang penuh emosi, lirik lagu dan musik mampu mengungkapkan perasaan tokoh dengan cara yang estetis.

Dialog berupa lagu pada film ini telah dipikirkan secara detail hingga hampir setiap dialog mampu mendeskripsikan keadaan dan perasaan setiap tokoh di dalam frame, meskipun tokoh tersebut bukanlah tokoh yang sedang berdialog/bernyanyi. Dialog pada film ini menarik karena hampir setiap scene dengan dialog yang dilagukan selalu menyelipkan beberapa montage. Tujuannya untuk menunjukkan berbagai peristiwa yang terjadi di berbagai tempat yang berbeda namun masih berhubungan erat dengan tokoh yang menyanyikan dialog tersebut. 
Film The Greatest Showman memiliki satu orang tokoh yang menjadi fokus utama dari cerita dalam film. Tokoh tersebut adalah Phineas Taylor Barnum atau yang kerap disebut P. T. Barnum. Tokoh utama disebut juga sebagai tokoh protagonis atau pahlawan dalam cerita (Grafinkel 2007, 23). Tokoh ini merupakan tokoh yang menjadi pusat penceritaan dalam film di mana ia memiliki tujuan dan kebutuhan. Cerita dalam sebuah film akan menyoroti bagaimana tokoh ini berjuang meraih tujuannya.

Penelitian ini akan membahas tentang bagaimana tiga dimensi karakter tokoh P. T. Barnum pada film musikal The Greatest Showman dan bagaimana karakter tokoh P. T. Barnum dibangun melalui dialog. Tujuan dari penelitian ini antara lain mendeskripsikan tiga dimensi karakter tokoh P. T. Barnum melalui dialog dan memaparkan tentang bagaimana karakter tokoh P. T. Barnum dibangun melalui dialog.

\section{Metode Penelitian}

Metode yang digunakan dalam penelitian ini adalah metode penelitian kualitatif dengan pendekatan deskriptif. Penelitian ini akan mengumpulkan data berupa teks, yaitu transkrip atau breakdown dari Film The Greatest Showman. Data berupa breakdown yang memuat dialog akan diteliti, dieksplorasi dan dipahami dengan mengacu pada teori film dialogue, hingga menghasilkan penjabaran dan gambaran deskriptif pembangunan karakter tokoh utama.

Metode yang akan digunakan dalam pengumpulan data adalah dokumentasi dan observasi. Proses pengumpulan data melalui metode dokumentasi akan dimulai dengan mencari file film musikal The Greatest Showman, mencari naskah film musikal The Greatest Showman dan mengunduh beberapa video di balik layar pembuatan film The Greatest Showman sebagai referensi. Peneliti tidak berhasil mendapatkan naskah final atau naskah terakhir dari film The Greatest Showman, namun peneliti mendapatkan naskah draft 20 April 2015 yang dijadikan sebagai referensi dalam penulisan breakdown (data penelitian).

Tahap pengumpulan data selanjutnya adalah observasi. Observasi akan dilakukan dengan menonton dan mengamati film musikal The Greatest Showman melalui media player yang tersedia. Observasi dilakukan menggunakan fitur seperti A-B Repeat, Screencapture, dan penanda/marking file yang memudahkan proses pengamatan film.

\section{Pembahasan}

Data utama dari penelitian ini adalah film musikal The Greatest Showman. Setelah data berupa file film diperoleh, proses selanjutnya adalah mengamati data dengan menonton film The Greatest Showman. Setelah mengolah data dengan menonton dan mengobservasi film The Greatest Showman, 
maka didapatkan data breakdown film berupa 65 scene film dengan 95 montage .

Breakdown film dari setiap scene akan dianalisis dalam dua tahap. Tahap pertama adalah analisis pembangunan karakter tokoh utama dalam scene melalui media dialog dan lirik lagu. Kedua adalah analisis pembangunan karakter tokoh utama dalam scene melalui media visual.

Setelah data diamati dengan saksama, peneliti akan membuat breakdown scene dari film The Greatest Showman. Breakdown scene dalam penelitian ini merupakan transkrip dari adegan dan dialog film The Greatest Showman yang dikemas dalam format skenario film fiksi dan mengacu pada format naskah film The Greatest Showman draft 20 April 2015.

Tahap penelitian selanjutnya adalah menganalisis pembangunan karakter tokoh $\mathrm{P}$. T. Barnum melalui unsur audio yang mencakup dialog dan lirik lagu serta melalui unsur visual. Dialog akan menjadi kajian utama dalam penelitian ini, sedangkan visual akan digunakan sebagai analisis pelengkap.

Proses analisis pembangunan karakter yang pertama adalah analisis pembangunan karakter melalui unsur audio yaitu dialog dan lirik lagu. Dialog yang akan dianalisis pada penelitian ini adalah dialog dari tokoh utama yaitu P. T. Barnum dan dialog dari tokoh-tokoh lain yang sedang membicarakan tokoh P. T. Barnum atau dialog tokoh lain yang masih memiliki hubungan sebab akibat dengan tokoh P. T. Barnum.

Pembangunan karakter melalui dialog akan dianalisis menggunakan teori Film dialogue dari Sarah Kozloff. Analisis akan dimulai dengan mengamati dan mendeskripsikan fungsi dialog yang terdiri dari identifikasi tokoh, tindakan/aksi verbal, perwujudan karakter, realitas tokoh dan eksploitasi sumber bahasa.

Analisis dialog akan dilanjutkan dengan mendeskripsikan struktur dialog dan gaya dialog yang terdiri dari kuantitas dialog, jumlah partisipan, interaksi dalam dialog, bahasa asing, dialek, repetisi, ritme dan surprise. Proses selanjutnya adalah mendeskripsikan integrasi dialog dengan unsur sinematik lainnya yang mencakup performance tokoh, shot and scale serta sound design.

Setelah menganalisis dialog di dalam breakdown scene dan mengobservasi data film, maka akan diperoleh hasil analisis berupa kemunculan dimensi karakter tokoh P. T. Barnum di dalam scene yang dianalisis. Dimensi karakter tokoh yang muncul akan dikumpulkan di dalam tabel analisis penjabaran tiga dimensi karakter tokoh P. T. Barnum dan dikelompokkan sesuai dengan dimensinya, yaitu dimensi fisiologi, sosiologi dan psikologi.

Selain memperoleh data berupa dimensi karakter tokoh, melalui analisis dialog akan dihasilkan pula data berupa 
penjabaran tentang bagaimana dimensi karakter tokoh dapat muncul atau dapat ditunjukkan melalui media dialog dan lirik lagu. Hasil penelitian berupa penjabaran pembangunan karakter tokoh utama melalui dialog akan dikumpulkan dalam tabel hasil analisis pembangunan karakter melalui dialog.

Mengingat bahwa karya film merupakan sebuah media audio-visual, maka penelitian tidak hanya menganalisis karakter melalui dialog dan lirik lagu saja, melainkan tetap memperhatikan unsur visual di dalamnya. Analisis unsur visual akan dilakukan dengan mengacu pada teori Karakterisasi Tokoh dari Joseph M. Boggs.

Proses analisis pembangunan karakter melalui unsur visual akan dilakukan dengan cara mengobservasi data film, kemudian mendeskripsikan penampilan, aksi eksternal, aksi internal, reaksi tokoh lain, kontras, pengulangan karakter/leitmotif dan pemilihan nama. Melalui analisis unsur visual, akan diperoleh data berupa kemunculan dimensi karakter tokoh P. T. Barnum. Dimensi karakter tokoh yang muncul melalui unsur visual juga akan dikumpulkan di dalam tabel hasil analisis sesuai dengan kategori dimensi karakter, yaitu dimensi fisiologi, sosiologi dan psikologi.

Hasil analisis berupa tiga dimensi karakter tokoh P. T. Barnum akan dijabarkan menggunakan teori Tiga Dimensi Tokoh dari Lajos Egri. Dimensi fisiologi akan dijabarkan dengan menyebutkan gender, usia, berat badan, tinggi badan, warna rambut, warna mata, warna kulit, postur, penampilan, cacat/kelainan fisik dan keturunan.

Dimensi sosiologi akan dijabarkan dengan menyebutkan kelas sosial, pekerjaan, pendidikan, kehidupan di rumah, agama, suku, negara, peran di komunitas, status politik dan hobi. Dimensi yang terakhir yaitu dimensi psikologi akan dijabarkan dengan menyebutkan orientasi seksual, ambisi/tujuan hidup, halangan, watak, cara bersikap, kepribadian, kemampuan dan kualitas.

Kategori kepribadian pada dimensi psikologi akan dianalisis menggunakan teori tipe kepribadian dari Isabel Briggs Myers dan Peter Briggs Myers. Teori ini akan digunakan untuk menganalisis tipe kepribadian dari tokoh untuk menemukan apakah tokoh termasuk tipe kepribadian ekstrovert, introvert atau ambivert.

Scene 28 akan digunakan sebagai contoh analisis dari total 65 scene yang telah diteliti karena scene ini dapat menjadi representasi analisis pembangunan karakter tokoh utama yang memuat banyak komponen dialog di dalamnya dan menghasilkan beberapa dimensi karakter yang penting dalam penelitian. 
Tabel 1 . 1 Cuplikan Breakdown dan Analisis Scene 28

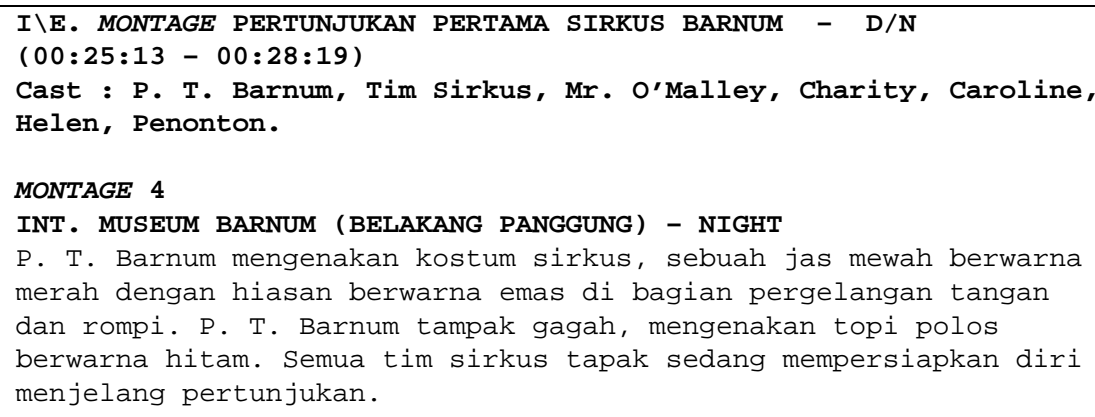

P. T. Barnum mengambil bantal salah seorang tim sirkus yang tidur di saat teman lainnya bersiap-siap, kemudian memasukkan bantal di dalam perut Pria Terberat Di Dunia. P. T. Barnum mengambil tali dari salah seorang tim sirkus lalu menalikannya pada kaki Vasily Palvos. P.T.Barnum membantu anggota sirkus bersiap-siap.

\section{P. T. BARNUM}

AND THE WORLD BECOMES A FANTASY. AND YOU'RE MORE THAN YOU COULD EVER BE. CAUSE YOU'RE DREAMING WITH YOUR EYES WIDE $O P E N$.

(DAN SAAT DUNIA MENJADI SEBUAH FANTASI. DAN KAU LEBIH DARI APA YANG KAU KIRA. KARENA KAU BERMIMPI DENGAN MATA YANG TERBUKA LEBAR.)

P. T. Barnum membantu Vasily Palvos berdiri, Vasily Palvos ternyata hilang keseimbangan dan hendak jatuh tapi teman-teman sirkus membantu mencegahnya.

Whoa...

\section{VASILY PALVOS}

(Waduh...)

\section{P. T. BARNUM}

AND YOU KNOW YOU CAN'T GO BACK AGAIN TO THE WORLD THAT YOU WERE LIVING IN.

(DAN KAU TAHU KAU TAK AKAN BISA HIDUP DI DUNIAMU YANG DULU LAGI)

P. T. Barnum melihat Lettie Lutz mengintip melalui tirai panggung. Lettie Lutz melihat kerumunan penonton dan tampak gugup. P. T. Barnum menghampiri Lettie Lutz.

\section{P. T. BARNUM}

CAUSE YOU'RE DREAMING WITH YOUR EYES WIDE OPEN. SO COME ALIVE!

(KARENA KAU BERMIMPI DENGAN MATA YANG TERBUKA LEBAR. JADI, HIDUPLAH!)

Vasily Palvos hilang keseimbangan, tim sirkus tidak mampu menghadangnya, kemudian mereka secara tidak sengaja menjadi maju ke panggung. Vasily Palvos bisa berhenti setelah berada di depan panggung. Tampak para penonton yang sangat terkejut melihat orang-orang unik di hadapan mereka. P. T. Barnum tampak panik, kemudian melihat Lettie Lutz yang juga tampak panik dan gugup hanya berdiri di balik tirai. P. T. Barnum menghampiri Lettie. 
Sense Vol 3 | No 2 | November 2020

P.T. BARNUM
Lettie! Lettie! They're waiting!
(Lettie! Lettie! Mereka menunggu)

LETTIE LUTZ

For what?

(Menunggu apa?)

For you.

P. T. BARNUM

(Menunggumu)

Oh, No.

LETTIE LUTZ

(Oh, Tidak)

\section{P. T. BARNUM}

They don't know it yet... but they are gonna love you.

Trust me.

(Mereka belum tahu, tapi mereka akan menyukaimu. Percayalah padaku.)

P. T. Barnum mengarahkan Lettie Lutz untuk keluar, menuju panggung. Di sisi lain, P. T. Barnum melihat Charles Stratton (Tom Thumb) tampak sedang menyibukkan diri dengan bersiap-siap, tapi tidak segera bergegas menuju panggung. P. T. Barnum mendatangi Tom Thumb.

Tom! Up! Up!

\section{P. T. BARNUM}

(Tom! Naik! Naik!)

P. T. Barnum menaikkan Charles Stratton di atas kuda dan membantunya merapikan kostum. Charles Stratton tampak cemberut dan tidak percaya diri.

\section{P. T. BARNUM}

I SEE IT IN YOUR EYES. YOU BELIEVE THAT LIE. THAT YOU NEED TO HIDE YOUR FACE.

(AKU MELIHAT DALAM MATAMU. KAU PERCAYA PADA KEBOHONGAN ITU. BAHWA KAU HARUS MENYEMBUNYIKAN WAJAHMU.)

Di panggung, terlihat seorang gadis kecil yang menonton pertunjukkan keluar dari persembunyiannya di balik badan ibunya, lalu melihat ke arah tim sirkus dan tersenyum. Lettie Lutz tampak takut, namun tersenyum ke arah penonton ketika melihat seorang anak laki-laki dengan penyangga kaki tersenyum ke arahnya.

AFRAID TO STEP OUTSIDE.

(TAKUT UNTUK MELANGKAH KELUAR.)

Pria Terberat Di Dunia yang semula panik, kini tampak membusungkan dada dan melihat ke arah penonton dengan percaya diri.

\section{P. T. BARNUM}

SO YOU LOCK THE DOOR. BUT DON'T YOU STAY THAT WAY!

(JADI KAU MENUTUP PINTU. TAPI JANGANLAH HIDUP SEPERTI ITU!)

Di belakang panggung, tampak P. T. Barnum menepuk pantat kuda yang ditunggangi oleh Tom Thumb. Kuda pun melaju ke depan panggung. Tom Thumb kesulitan menjaga keseimbangan namun akhirnya bisa mengendalikan kuda di atas panggung. Tim Sirkus lainnya tampak mulai berani dan percaya diri.

LETTIE LUTZ

NO MORE LIVING IN THOSE SHADOWS. YOU AND ME, WE KNOW HOW THAT GOES.

(TAK LAGI HIDUP DALAM BAYANGAN ITU. KAU DAN AKU, KITA TAHU BAGAIMANA RASANYA) 


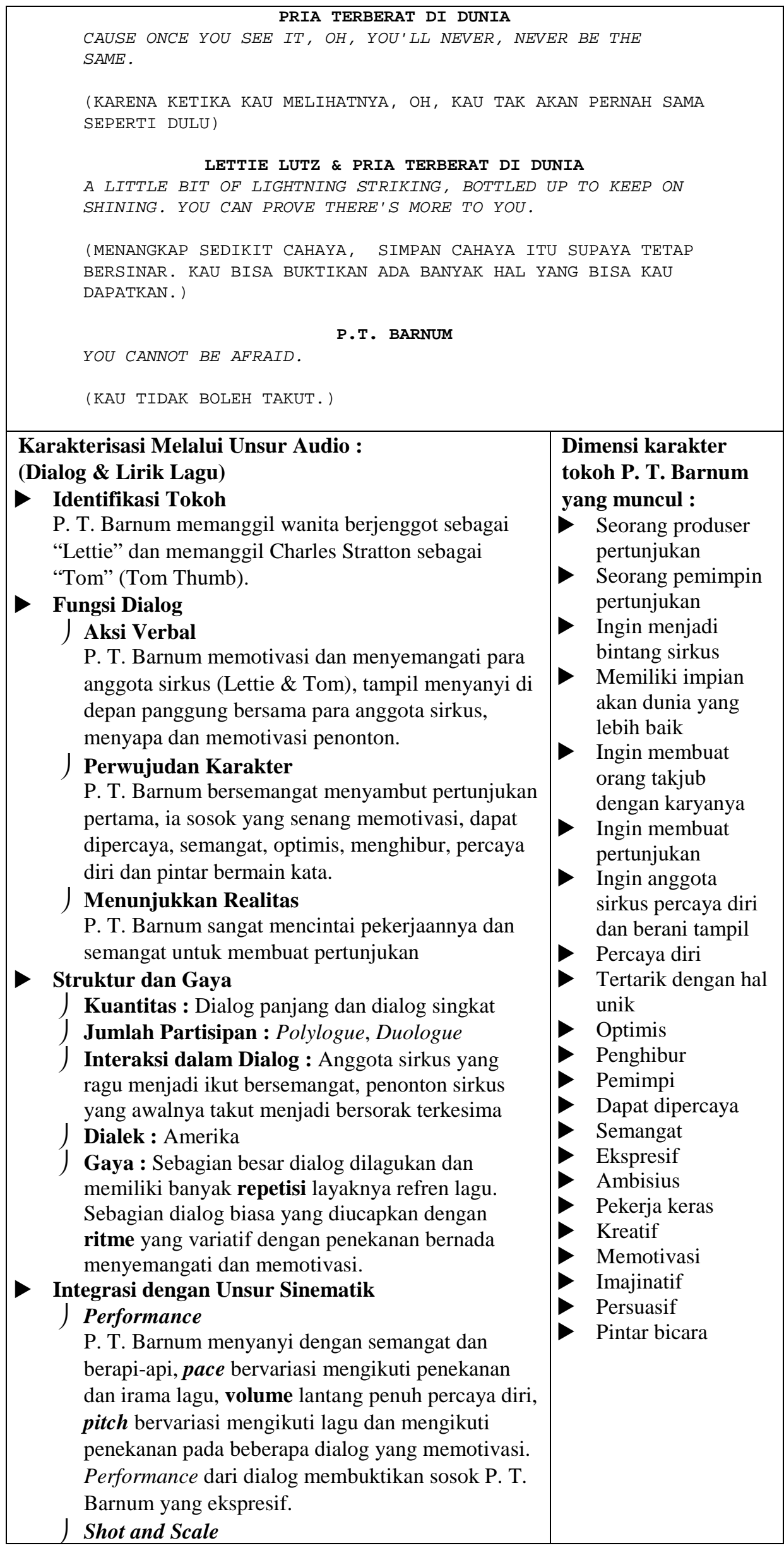




\begin{tabular}{|c|c|}
\hline $\begin{array}{l}\text { Beberapa shot off screen memiliki Voice over yaitu } \\
\text { lagu yang dinyanyikan P. T. Barnum. VO tersebut } \\
\text { mendeskripsikan adegan dalam setiap shot } \\
\text { (Montage 1, } 2 \text { dan 3) } \\
\text { - Sound design } \\
\text { Dialog yang dinyanyikan dalam scene ini adalah } \\
\text { penggalan original soundtrack berjudul "Come } \\
\text { Alive" dengan musik yang didominasi ritme cepat } \\
\text { dan bersemangat. }\end{array}$ & \\
\hline $\begin{array}{l}\text { Karakterisasi Melalui Unsur Visual } \\
\text { Penampilan } \\
\text { Kostum sirkus mewah berwarna merah-hitam } \\
\text { berhiaskan ornamen emas } \\
\text { Aksi Eksternal } \\
\text { P. T. Barnum berganti baju mengenakan kostum } \\
\text { pertunjukan yang mewah, membantu anggota sirkus } \\
\text { bersiap-siap memakai kostum, memasukkan bantal di } \\
\text { perut Pria Terberat di Dunia, memakaikan egrang untuk } \\
\text { Raksasa Irlandia, menghibur dan meyakinkan Lettie } \\
\text { Lutz untuk tampil, memotivasi Charles untuk tampil } \\
\text { dan menepuk pantat kuda supaya bergerak. P. T. } \\
\text { Barnum membawa semua anggota sirkus tampil di } \\
\text { panggung dan memimpin pertunjukan dengan tarian } \\
\text { dan nyanyian penuh semangat di panggung sirkus. } \\
\text { Aksi Internal } \\
\text { P. T. Barnum tampak sangat puas dan bahagia melihat } \\
\text { para penonton yang menikmati pertunjukan (Montage } \\
\text { 5) } \\
\text { Reaksi Tokoh Lain } \\
\text { Lettie Lutz semula takut dan ragu, kemudian menjadi } \\
\text { berani setelah dimotivasi oleh P. T. Barnum dan } \\
\text { setelah melihat senyum penonton. Charles Stratton } \\
\text { semula masih takut dan ragu, kemudian menjadi } \\
\text { semangat setelah dimotivasi oleh P. T. Barnum dan } \\
\text { menikmati suasana pertunjukan. } \\
\text { Pengulangan Karakter / Leitmotif } \\
\text { P. T. Barnum kembali memotivasi orang-orang, melalui } \\
\text { lirik demi lirik lagu "Come Alive" dan melalui dialog } \\
\text { dengan Lettie Lutz, "They don't know it yet... but they } \\
\text { are gonna love you. Trust me" }\end{array}$ & $\begin{array}{l}\text { Dimensi karakter } \\
\text { tokoh P. T. Barnum } \\
\text { yang muncul : } \\
\text { Kelas sosial } \\
\text { menegah ke atas } \\
\text { Keluarga } \\
\text { mendukung } \\
\text { pekerjaan } \\
\text { Dibenci kritikus } \\
\text { seni dan jurnalis } \\
\text { kota } \\
\text { Aktif/Gesit } \\
\text { Percaya diri } \\
\text { Tertarik dengan hal } \\
\text { unik } \\
\text { Optimis } \\
\text { Penghibur } \\
\text { Pemimpi } \\
\text { Semangat } \\
\text { Ekspresif } \\
\text { Pekerja keras } \\
\text { Kreatif } \\
\text { Imajinatif } \\
\text { Memotivasi } \\
\text { Ambisius }\end{array}$ \\
\hline
\end{tabular}

\section{Hasil Penelitian}

Berikut hasil penelitian yang didapatkan dari keseluruhan analisis pembangunan karakter tokoh utama melalui dialog pada film musikal "The Greatest Showman" :

\section{Dimensi Fisiologi Tokoh P. T. Barnum}

Analisis pembangunan karakter tokoh utama, yaitu tokoh P. T. Barnum menghasilkan temuan dimensi fisiologi tokoh, antara lain tokoh adalah seorang laki-laki, keturunan Amerika, bernama Phineas Taylor Barnum yang tidak memiliki cacat fisik apa pun. Saat berusia 10 tahun, P. T. Barnum memiliki tinggi badan sekitar $168 \mathrm{~cm}$, berat badan sekitar $45 \mathrm{~kg}$, badan tinggi, kurus, kulit putih, mata besar, alis tebal, bibir tipis, 
rambut agak gondrong dan bergelombang, rambut berwarna coklat tua, pakaian yang dikenakan selalu kumal dan lusuh, sepatunya juga rusak dan badannya sering kotor.

Saat berusia 40 tahunan, P. T. Barnum memiliki tinggi badan sekitar $188 \mathrm{~cm}$, berat badan sekitar $85 \mathrm{~kg}$, memiliki tubuh yang tinggi, berisi, gagah, rambut tokoh pendek, berwarna coklat tua dan bergelombang. P. T. Barnum selalu menggunakan setelan kemeja dan celana kain, mulai dari kemeja sederhana sampai jas yang mewah. P. T. Barnum juga sering menggunakan aksesoris tambahan berupa topi, syal, tongkat dan jam saku. Saat tampil di panggung, P. T. Barnum menggunakan kostum sirkus mewah yang dinominasi warna merah dan emas.

Dimensi fisiologi tokoh P. T. Barnum pada film musikal The Greatest Showman muncul melalui media dialog dan visual. Kemunculan dimensi fisiologi tokoh melalui dialog cenderung terbatas. Hal ini dapat dilihat dari jumlah kemunculan dimensi karakter yang kontras. Frekuensi kemunculan dimensi karakter melalui dialog sebanyak 48 kali sedangkan kemunculan dimensi karakter melalui visual sebanyak 406 kali.

Dialog hanya mampu menunjukkan dimensi karakter yang meliputi jenis kelamin, nama dan keturunan. Jenis kelamin tokoh yang ditunjukkan melalui dialog dapat dilihat pada scene $2,14,16,17,18,22,26,27$, dst. Jenis kelamin tokoh dan nama tokoh dapat diketahui melalui bagaimana tokoh memperkenalkan diri dan menyebutkan namanya, serta melalui reaksi tokoh lain yang memanggil nama tokoh maupun sekedar menyapa tokoh dengan sebutan "Sir" , "M r." , "D addy", dll.

Keturunan tokoh didapatkan melalui dialog dari Philio Barnum (Ayah P. T. Barnum) yang tampak pada scene 2 dan scene 3. Pada scene tersebut, Philio Barnum berbicara dengan logat Amerika. Pengungkapan keturunan melalui media visual juga memperkuat hasil temuan ini, antara lain ekspresi dari ayah tokoh dan visual bendera Amerika Serikat pada scene 11.

Analisis pembangunan karakter tokoh melalui media visual pada penelitian ini mengungkapkan tentang ciri khas dari penampilan P. T. Barnum yaitu P. T. Barnum sering mengenakan aksesoris topi, hal ini dapat ditunjukkan melalui kemunculan tokoh P. T. Barnum yang menggunakan topi pada scene 12, 19, 20, 21, 25, dst. Terdapat total 17 scene.

Melalui hasil analisis dimensi fisiologi tokoh P. T. Barnum dapat disimpulkan bahwa dialog memang 
dapat mengungkapkan dimensi fisiologi tokoh namun dialog bukan media yang paling efektif untuk menunjukkan fisiologi dari tokoh. Dialog pada film musikal The Greatest Showman hanya mampu mengungkapkan dimensi fisiologi tokoh yang meliputi nama, jenis kelamin dan keturunan.

\section{Dimensi Sosiologi Tokoh P. T.} Barnum

Analisis pembangunan karakter tokoh utama menghasilkan temuan dimensi sosiologi P. T. Barnum yang beragam. Melalui hasil analisis dapat dilihat bahwa P. T. Barnum adalah seorang yang berasal, berkebangsaan dan tinggal di Amerika Serikat. P. T. Barnum seseorang yang berasal dari kalangan kelas sosial menengah ke bawah (miskin) yang mengalami stratifikasi sosial ke kelas sosial menengah hingga ke kelas sosial atas.

P. T. Barnum digambarkan sebagai seorang yang tidak pernah menempuh pendidikan secara formal. Selama remaja hingga dewasa, P. T. Barnum telah menggeluti berbagai pekerjaan, antara lain pernah menjadi seorang penjual koran saat remaja, kemudian ketika dewasa menjadi seorang karyawan (akuntan) di sebuah perusahaan dagang, lalu beralih profesi menjadi seorang pemilik museum, produser pertunjukan sekaligus pemimpin pertunjukan.

Kehidupan di rumah atau kehidupan keluarga P. T. Barnum juga dapat ditemukan di dalam analisis. Kondisi rumah atau kehidupan keluarga tersebut antara lain saat remaja, P. T. Barnum tinggal bersama ayahnya yang tegas, agak kasar dan suka memerintah. Setelah ayahnya meninggal, P. T. Barnum hidup seorang diri. Setelah dewasa, P. T. Barnum menikah dengan Charity Hallett dan memiliki dua orang anak perempuan bernama Caroline dan Helen.

Keluarga P. T. Barnum dan Charity Hallet adalah keluarga yang harmonis dan romantis. P. T. Barnum adalah sosok yang perhatian dan menyayangi keluarga. Tetapi ada masa di mana hubungan P. T. Barnum dengan keluarga sedang buruk, sampai pada suatu ketika P. T. Barnum ditinggalkan oleh istri dan anak-anaknya. Namun kondisi keluarga yang kacau tidak berlangsung lama, karena P. T. Barnum segera meminta maaf atas tindakannya dan memperbaiki hubungan keluarganya.

Di dalam film The Greatest Showman tidak ditunjukkan secara jelas tentang agama P. T. Barnum, namun ayah P. T. Barnum dimakankan secara kristiani (Kristen/Katolik). P. T. Barnum 
memiliki status politik yang cukup baik. P. T. Barnum berteman dengan Ratu Victoria dari Inggris dan berteman dengan para politikus Amerika pada masanya.

Peran P. T. Barnum di dalam komunitas juga beragam, antara lain $\mathrm{P}$. T. Barnum adalah seorang pemilik Museum Barnum, seorang produser pertunjukan yang juga memimpin pertunjukan, namun ia dibenci oleh serang kritikus seni dan jurnalis ternama di New York, Amerika Serikat. Selian itu, P. T. Barnum juga dibenci oleh sebagian kalangan masyarakat dan tidak dianggap di masyarakat. Semasa hidupnya, sejak remaja hingga dewasa, P. T. Barnum memiliki hobi yaitu ia senang menghibur orang di sekitarnya. Ia juga senang melakukan atraksi dan tampil di depan umum.

Berbagai dimensi sosiologi tokoh P. T. Barnum pada film musikal The Greatest Showman muncul melalui media dialog dan media visual. Hasil penelitian menunjukkan bahwa frekuensi kemunculan berbagai dimensi sosiologi dari tokoh P. T. Barnum yang ditunjukkan melalui media dialog adalah sebanyak 298 kali, sedangkan frekuensi kemunculan melalui visual didapat sebanyak 260 kali.

Frekuensi kemunculan dimensi sosiologi ini menunjukkan bahwa pada film The Greatest Showman, dialog memiliki peran yang kuat dalam membangun dimensi sosiologi dari tokoh P. T. Barnum. Dialog menjadi media yang dominan dalam memunculkan dimensi sosiologi dari tokoh. Dimensi sosiologi yang paling dominan dimunculkan melalui dialog adalah informasi tentang suku atau negara dari P. T. Barnum yaitu ia berasal dan tinggal di Amerika.

Jumlah keseluruhan dari kemunculan dimensi sosiologi dari tokoh P. T. Barnum yang muncul melalui dialog adalah sebanyak 298 kali, sedangkan kemunculan dimensi sosiologi melalui visual sebanyak 260 kali. Dari segi jumlah, frekuensi kemunculan dimensi sosiologi melalui media visual memang lebih sedikit, namun terdapat beberapa unsur dimensi sosiologi yang hanya muncul secara visual.

Unsur dimensi sosiologi tokoh P. T. Barnum yang hanya muncul melalui media visual ditemukan pada scene 11 , di mana scene tersebut mampu menunjukkan pendidikan P. T. Barnum (tidak bersekolah formal), kehidupan di rumah atau kondisi keluarga $\mathrm{P}$. T. Barnum semasa remaja (hidup seorang diri setelah ayahnya meninggal) dan agama P. T. Barnum (kristiani; Kristen/Katolik). 
Perbedaan jumlah frekuensi kemunculan dimensi sosiologi melalui dialog dan visual menunjukkan bahwa meskipun perbedaan jumlah tidak signifikan, namun pembangunan dimensi sosiologi tokoh P. T. Barnum pada film The Greatest Showman yang ditunjukkan melalui dialog lebih efektif dan memiliki peran yang lebih kuat daripada dimensi sosiologi yang muncul secara visual.

\section{Dimensi Psikologi Tokoh P. T.} Barnum

Analisis pembangunan karakter tokoh utama menghasilkan banyak temuan dimensi psikologi dari P. T. Barnum. P. T. Barnum pada film The Greatest Showman digambarkan sebagai sosok laki-laki yang memiliki orientasi seksual heteroseksual dan memiliki banyak sekali ambisi atau tujuan selama hidupnya.

Ambisi atau tujuan tersebut antara lain adalah ingin menjadi bintang pertunjukan, ingin memakai pakaian bagus, ingin dibela dan dilindungi ayah, ingin bermain dengan Charity, ingin hidup mewah, ingin berkembang, ingin mendirikan museum, ingin museumnya menghasilkan uang dan terkenal, ingin membuat orang takjub dengan karyanya, ingin membuat pertunjukan, ingin tim sirkus percaya diri dan berani, ingin anaknya bangga padanya, ingin menjadi orang terpandang, ingin berbaur dengan orang kaya, ingin diakui di masyarakat, ingin kembali membangun sirkus dan ingin menjadi pria yang lebih baik.

Analisis juga menunjukkan halangan atau ketidakpuasan dari P. T. Barnum, antara lain keluarganya miskin, berbeda kelas sosial dengan pujaan hati, merasa bosan dengan pekerjaan, dipecat, menjadi pengangguran, museum tidak laku, tidak dianggap di masyarakat, menjadi buah bibir di kota, anaknya malu pada pekerjaannya, sirkusnya dibenci masyarakat, museumnya kebakaran, kemudian bangkrut.

Melalui analisis, didapatkan pula berbagai watak yang terdapat pada diri P. T. Barnum antara lain ia adalah seorang yang penurut (semasa remaja), peduli, jujur, berani, percaya diri, tegas, keras kepala, egois, lucu, sopan/hormat, sensitif, optimis, penghibur, penyayang, suka bertualang, pemimpi, jahil, dapat diandalkan, nekat tegar, semangat, romantis, hangat, hiperbola, ekspresif, ambisius, pekerja keras, setia, sombong, serakah, rela berkorban dan tidak pendendam.

Bagaimana cara P. T. Barnum bersikap juga dapat dilihat melalui hasil analisis, antara lain P. T. Barnum cenderung pendiam saat di depan ayahnya, lembut dan penuh kasih pada Charity, ia juga sosok yang aktif/gesit, 
mencintai anak dan istri, membenci mertua, tertarik dengan hal unik, antisipatif, sarkastis, tidak suka kekerasan, tidak suka pada Mr. Bennett, gugup saat berada di lingkungan orang kaya, malu berhubungan dengan tim sirkus, bersikap dingin dan mengacuhkan anak istri, meninggalkan tim sirkus, pilih kasih, tidak memprioritaskan keluarga, bersikap dingin pada rekan kerja, dan juga menyayangi teman-teman.

Penjabaran dimensi psikologi yang ditemukan dalam analisis juga menunjukkan kemampuan dari P. T. Barnum yang kreatif, memotivasi, imajinatif, persuasif, pintar melihat peluang, memiliki wawasan luas, cerdik, pintar bicara dan mampu mempengaruhi orang lain.

Selain kemampuan, terdapat pula kualitas dari sosok P. T. Barnum yang muncul, antara lain P. T. Barnum adalah salah satu seniman pertunjukan terbaik di Amerika, ia juga seorang produser pertunjukan yang sukses, seorang pria yang humanis (tidak membeda-bedakan orang), dan sosok kepala rumah tangga yang penyayang, menyenangkan, pekerja keras, bertanggungjawab, dan berani mengakui kesalahan.

Melalui analisis, ditemukan bahwa di dalam film terdapat banyak dimensi psikologi dari P. T. Banrum yang dominan muncul melalui media dialog, antara lain ambisi dan tujuan hidupnya untuk berkembang, menjadi orang terpandang dan diakui dimasyarakat. Kemudian terdapat wataknya yang adalah sosok pemimpi dan ambisius. Terdapat pula kemampuannya yang memotivasi dan pintar bicara. Frekuensi kemunculan dimensi-dimensi tersebut lebih banyak ditunjukkan melalui dialog.

Media dialog tidak hanya mendominasi banyak kemunculan dimensi psikologi, tetapi juga terdapat beberapa dimensi psikologi P. T. Barnum yang hanya muncul melalui dialog, antara lain watak P. T. Barnum yang optimis (muncul pada sebanyak 29 scene), keras kepala (muncul pada sebanyak 2 scene), serakah (muncul pada sebanyak 1 scene), cara bersikap yang pilih kasih (muncul pada sebanyak 2 scene), kemampuan persuasif (muncul pada sebanyak 12 scene), dan wawasannya yang luas (muncul pada sebanyak 4 scene).

Di sisi lain, melalui hasil analisis dapat diketahui bahwa terdapat beberapa dimensi karakter yang hanya muncul melalui media visual, seperti keinginan P. T. Barnum untuk memakai pakaian bagus (saat remaja), keinginan untuk dibela Ayah, sifat penurut (saat remaja), sikap diam di depan Ayah (saat remaja) 
dan watak/sifat P. T. Barnum yang aktif/gesit.

Jumlah kemunculan dimensi psikologi tokoh P. T. Barnum melalui media dialog adalah 653 kali sedangkan jumlah kemunculan dimensi psikologi tokoh P. T. Barnum melalui media visual adalah 601 kali. Perbedaan frekuensi kemunculan dimensi psikologi ini menunjukkan bahwa dialog menjadi media yang jauh lebih efektif dan memiliki peranan yang kuat untuk memunculkan dimensi psikologi tokoh dalam film.

\section{Pembangunan Karakter Tokoh Melalui Dialog}

Dimensi karakter tokoh P. T. Barnum yang mencakup dimensi fisiologi, sosiologi dan psikologi muncul melalui dialog dengan cara mengidentifikasi dan mendeskripsikan fungsi dialog, struktur dan gaya dialog, serta integrasi dialog dengan unsur sinematik lainnya.

Fungsi dialog yang telah diidentifikasi dan dideskripsikan di dalam analisis antara lain adalah identifikasi tokoh, aksi verbal, perwujudan karakter, realitas tokoh dan eksploitasi sumber bahasa. Kemudian struktur dan gaya dialog yang diidentifikasi dan dideskripsikan meliputi kuantitas dialog, jumlah partisipan, interaksi dalam dialog, dialek, ritme, repetisi dan surprise.

Integrasi dialog dengan unsur sinematik lainnya yang telah diidentifikasi dan dideskripsikan adalah integrasi dialog dengan performance, integrasi dialog dengan shot and scale dan integrasi dialog dengan sound design (original soundtrack; dialog yang dinyanyikan).

Berbagai unsur yang telah diidentifikasi dan dideskripsikan pada tabel analisis tersebut adalah alat yang digunakan untuk menemukan dimensi karakter dari tokoh P. T. Barnum. Perwujudan karakter tokoh P. T. Banrum didapatkan melalui analisis relasi antara unsur-unsur pada fungsi dialog, struktur dan gaya dialog serta integrasi dialog dengan komponen sinematik lainnya.

Fungsi dialog untuk mengidentifikasi tokoh P. T. Barnum pada film The Greatest Showman menunjukkan bahwa dialog mampu mengungkapkan lokasi adegan, nama tokoh, tempat tinggal tokoh, asal tokoh, serta pengenalan tokoh-tokoh lain di sekitar tokoh utama. Fungsi identifikasi dapat ditemukan pada 44 scene dari total 65 scene yang dianalisis.

Fungsi dialog sebagai aksi/tindakan verbal pada film The Greatest Showman menunjukkan mampu menunjukkan bahwa dialog 
mampu menunjukkan dimensi karakter tokoh P. T. Barnum yang tidak dapat dimunculkan melalui visual, antara lain mengungkapkan tentang P. T. Barnum yang berbohong, P. T. Barnum yang meminta maaf, informasi dari tokoh lain tentang P. T. Barnum, sikap P. T. Barnum yang sarkastis, dsb. Aksi verbal ditemukan pada total 57 scene.

$$
\text { Fungsi dialog sebagai }
$$
perwujudan karakter dapat ditemukan pada 57 scene. Fungsi ini dapat ditemukan dengan mengidentifikasi dan menganalisis unsur dialog lain seperti aksi verbal, interaksi dalam dialog, gaya dialog, dan performance. Perwujudan karakter mampu mengungkapkan bagaimana watak tokoh P. T. Barnum, bagaimana cara P. T. Barnum bersikap dan bagaimana pandangan tokoh lain tentang sosok P. T. Barnum.

Fungsi dialog dalam menunjukkan realitas tokoh muncul pada 46 scene. Fungsi ini mampu merepresentasikan percakapan seharihari dan kehidupan sehari-hari dari tokoh P. T. Barnum. Identifikasi dan deskripsi dari realitas tokoh dapat menunjukkan bagaimana kondisi bisnis P. T. Barnum, bagaimana kondisi di rumah $\mathrm{P}$. T. Barnum, bagaimana hubungan P. T. Barnum dengan keluarga, dengan temanteman sirkus, dengan Jenny Lind, dengan mertua, dengan masyarakat, dsb.
Fungsi dialog pada eksploitasi sumber bahasa muncul pada sebanyak 14 scene. Fungsi ini mampu menunjukkan tentang humor/lelucon yang diucapkan P. T. Barnum, menunjukkan sifat P. T. Barnum yang sarkastis dan juga menyisipkan beberapa kata mutiara dari tokoh asli Phineas Taylor Barnum ke dalam dialog film.

Dimensi karakter P. T. Barnum yang muncul melalui dialog diperkuat dengan unsur struktur dialog dan gaya dialog. Struktur dan gaya dapat mengidentifikasi bagaimana cara P. T. Barnum berbicara, bagaimana sikap P. T. Barnum terhadap lawan bicara, dsb.

Unsur kuantitas dialog dan jumlah partisipan di dalam klasifikasi struktur dan gaya dialog diidentifikasi menjadi dialog panjang, dialog singkat, monolog (tokoh berbicara pada diri sendiri), duologue (percakapan antara dua orang) dan polylogue (percakapan lebih dari dua orang).

Identifikasi dari unsur ini mampu mengungkapkan tentang tokoh P. T. Banrum yang selalu mendominasi percakapan, kemampuannya yang pintar bicara, sifatnya yang jujur, dsb. Kuantitas dialog dan jumlah partisipan dapat ditemukan pada 57 scene.

Unsur interaksi dalam dialog muncul pada 57 scene di dalam film. Interaksi pada dialog mampu 
mengungkapkan karakter tokoh P. T. Barnum yang sering berada pada posisi superior, mendominasi, dan mengungkapkan apakah P. T. Barnum bersikap sopan pada lawan bicara, apakah P. T. Barnum memperhatikan dan mendengarkan lawan bicara, dsb. Interaksi dalam dialog juga mampu mengungkapkan tentang bagaimana tokoh-tokoh lain memperlakukan P. T. Barnum.

Dialek pada setiap dialog mampu mengungkapkan banyak hal tentang P. T. Barnum berserta tokoh-tokoh lain di sekitarnya. Dialek mengungkapkan identitas ayah dari P. T. Barnum yang adalah orang Amerika, dialek juga mengungkapkan identitas P. T. Barnum yang berasal dan tinggal di Amerika. Dialek dapat ditemukan pada 57 scene dalam film.

Unsur terakhir pada klasifikasi struktur dan gaya dialog adalah repetisi, ritme dan surprise. Ketiga unsur ini mampu mengungkapkan tentang bagaimana cara tokoh P. T. Barnum berbicara dan apa makna dari dialog yang diucapkannya. Repetisi pada dialog P. T. Barnum, misalnya, dapat mengungkapkan banyak hal.

Pertama, repetisi dapat menandakan bahwa P. T. Barnum adalah sosok yang tegas dan bersungguhsungguh pada apa yang diucapkannya.
Repetisi dalam hal ini akan menekankan keseriusan pada dialog P. T. Barnum. Di sisi lain, repetisi juga dapat menandakan P. T. Barnum yang memiliki keraguan dan gugup akan sesuatu, sehingga dialognya diucapkan secara terbata-bata. Dialog yang mengandung unsur repetisi ditemukan pada sejumlah 27 scene.

Gaya dialog selanjutnya adalah ritme. Semua dialog pada film The Greatest Showman memiliki ritme. Ritme dapat ditemukan pada 57 scene dalam film. Ritme dapat mengungkapkan bagaimana kondisi emosional P. T. Barnum. Ritme juga menyesuaikan dengan adegan. Contoh, ritme cepat bisa mengungkapkan semangat dari P. T. Barnum, namun juga bisa mengungkapkan amarah dari P. T. Barnum.

Selain fungsi dialog, struktur dialog dan gaya dialog, terdapat integrasi dialog dengan unsur sinematik lainnya. Integrasi pertama adalah integrasi dialog dengan performance dari aktor. Unsur yang satu ini mirip seperti gaya dialog, yaitu terdiri dari pitch, pace dan power/volume. Integrasi ini mengungkapkan bagaimana tokoh $\mathrm{P}$. T. Barnum diperankan dengan sangat baik oleh aktor Hugh Jackman.

Perpaduan antara pitch, pace dan power dalam dialog P. T. Barnum mampu mengungkapkan banyak hal 
tentang P. T. Barnum, antara lain memperkuat makna dari kata yang diucapkan, menandakan keseriusan, menunjukkan sifat P. T. Barnum yang ekspresif, lucu, tegas, penyayang, dsb. Integrasi dialog dan performance muncul pada 57 scene dalam film.

Salah satu integrasi dialog dengan unsur sinematik yang menarik dalam film ini adalah integrasi dialog dengan shot and scale. Pada sejumlah 13 scene dalam film The Greatest Showman, terdapat dialog off screen (dialog dalam bentuk voice over) yang sengaja dimunculkan untuk menciptakan makna tertentu. Penyajian inilah yang mampu mengungkapkan identitas tokoh.

Sebagai contoh, pada analisis Scene 52, terdapat kemunculan tokoh P. T. Banrum secara visual namun dialog di dalamnya adalah dialog dari tokoh Charity yang menyanyikan lagu, mengungkapkan kerinduan sekaligus kesedihannya karena ditinggalkan oleh P. T. Barnum. Dalam scene tersebut, banyak sekali sisipan montage yang memuat visual dari berbagai tokoh, seperti Charity, Caroline, Helen, Philip Carlyle, Tim Sirkus, Jenny Lind dan P. T. Barnum.

Integrasi dialog dengan shot \& scale di dalam film ini mampu mengungkapkan kondisi kehidupan masing-masing tokoh yang muncul di dalam frame meskipun hanya ada satu tokoh saja yang berbicara dalam wujud lagu. Hal yang menarik pada analisis ini adalah setiap dialog yang diucapkan pada setiap shot mampu merepresentasikan kondisi emosional dari setiap tokoh yang ada di dalam shot, meskipun dialog tersebut adalah dialog dari tokoh lain.

Unsur integrasi tersebut mampu mengungkapkan banyak hal tentang karakter dari tokoh P. T. Barnum, yaitu berbagai kualitas dan kemampuannya, antara lain bagaimana perilaku P. T. Barnum mampu mempengaruhi Philip Carlyle untuk mengurus sirkus, bagaimana keluarga P. T. Barnum begitu merindukan dan mencintainya, bagaimana Jenny Lind begitu mengaguminya, dsb.

Integrasi dialog yang terakhir adalah integrasi dengan sound design. Sebagai sebuah film musikal, The Greatest Showman tidak lepas dari kekuatan unsur musik di dalamnya, baik itu musik skor, efek suara, dialog dan soundtrack. Unsur musik yang paling dominan adalah soundtrack. Integrasi dialog dengan sound design dapat ditemukan pada 25 scene.

Dialog yang dinyanyikan mampu mengungkapkan banyak dimensi karakter dari P. T. Barnum seperti watak P. T. Barnum yang semangat, optimis, 
pemimpi, tegar, kemudian pekerjaannya sebagai pemilik museum, produser pertunjukan sekaligus pemimpin pertunjukan, kemampuannya yang kreatif, imajinatif dan persuasif, dsb.

Dari total 65 scene yang telah dianalisis, terdapat 9 silent scene, yaitu scene tanpa P. T. Barnum dan atau scene di mana P. T. Barnum tampak dalam frame, namun tidak berdialog atau diam. Meskipun tanpa tokoh P. T. Barnum, dialog tokoh lain tetap mampu menunjukkan berbagai dimensi karakter dari tokoh P. T. Barnum yang ditinjau melalui reaksi tokoh lain.

"Reaksi Tokoh Lain", "Pemilihan Nama" dan "Pengulangan Karakter / Leitmotif" merupakan tiga dari beberapa unsur karakterisasi tokoh di dalam teori Joseph M. Boggs. Namun hasil penelitian menunjukkan bahwa ketika kategori ini tidak hanya mencakup unsur visual saja, melainkan juga unsur dialog. Melalui penelitian ini, dapat ditemukan bahwa dimensi karakter tokoh utama tidak hanya ditinjau melalui dialog dari tokoh utama saja, melainkan juga dialog dari tokoh-tokoh lain di dalam film.

\section{Kesimpulan}

Rangkaian proses analisis pembangunan karakter tokoh utama melalui dialog pada film musikal The Greatest Showman yang dilakukan terhadap 64 scene film dengan 95 montage menunjukkan bahwa tiga dimensi karakter tokoh utama yaitu dimensi fisiologis, dimensi sosiologis dan dimensi psikologis dapat ditemukan melalui analisis dialog dan lirik lagu. Hasil penelitian menunjukkan bahwa dialog dan lirik lagu menjadi media pembangunan karakter tokoh yang kuat dan dominan di dalam film.

Dimensi karakter tokoh yang dominan ditunjukkan melalui dialog banyak ditemukan pada klasifikasi dimensi sosiologi dan dimensi psikologi. Hal ini mengindikasikan bahwa media karakterisasi yang dominan untuk menunjukkan dimensi sosiologi dan psikologi tokoh adalah dialog. Dominasi tersebut juga dapat dibuktikan melalui data jumlah frekuensi kemunculan dimensi karakter tokoh melalui dialog.

Hasil analisis juga menunjukkan bahwa terdapat beberapa kemunculan dimensi fisiologi tokoh yang ditunjukkan melalui dialog. Namun pada dimensi fisiologi, media karakterisasi yang dominan adalah media visual karena banyak unsur fisiologi yang memang hanya dapat ditunjukkan melalui visualisasi dari tokoh yang bersangkutan, seperti penampilan/gaya, tinggi badan, berat badan, dsb.

Meskipun demikian, dialog tetap menjadi media pembangunan karakter yang sangat penting dalam film musikal The Greatest Showman, karena dialog mampu menunjukkan aksi tokoh utama yang tidak dapat dimunculkan melalui visual, dialog 


\section{Alifia Nuralita Rezqiana, Siti Maemunah, Endang Mulyaningsih}

Pembangunan Karakter Tokoh Utama melalui Dialog pada Film Musikal "The Greatest Showman"

mampu menunjukkan komitmen dan kesungguhan tokoh utama dalam melakukan aksinya, dialog juga mampu menunjukkan bagaimana pandangan tokoh-tokoh lain terhadap tokoh utama yang pada praktiknya dapat menunjukkan bagaimana karakter dari tokoh utama.

Dialog yang disajikan dalam format lagu pada film musikal The Greatest Showman menjadi media pembangunan karakter yang kuat karena pada analisis scene yang memuat soundtrack, terdapat semua komponen fungsi dialog, terdapat struktur dan gaya dialog yang khas, dan juga terdapat integrasi dialog dengan tiga unsur sinematik yang menarik.

Dialog yang dinyanyikan pada film musikal The Greatest Showman mampu merepresentasikan karakter tokoh utama pada berbagai situasi penting, seperti masa ketika tokoh utama sedang dalam perjuangan mencapai tujuan, ketika tokoh utama menikmati kejayaan, sampai pada masa di mana tokoh utama berada pada titik terendah dalam perjalanan pencapaian tujuan.

Relasi antara fungsi dialog, struktur dan gaya dialog serta integrasi dialog dengan performance aktor, shot and scale dan sound design mampu memperkuat peran dialog dalam mewujudkan karakter tokoh. Interaksi dialog dengan shot and scale dan sound design pada film ini tidak hanya terbatas pada aksi tokoh utama saja, melainkan juga aksi dari tokoh-tokoh lain yang mendukung dan memperkuat karakter tokoh utama.

\section{Daftar Pustaka}

Altman, Rick. 2000. Film Genre. London: British Film Institute.

Biran, Misbach Yusa. 2010. Teknik Menulis Skenario. Jakarta: Fakultas Film dan Televisi Institut Kesenian Jakarta.

Boggs, Joseph M. 1992. The Art of Watching Film. Dialihbahasakan oleh Asrul Sani. Jakarta: Yayasan Citra.

Dennis W. Petrie; Joseph M. Boggs. 2012. The Art of Watching Films. 8th. New York: McGraw-Hill.

Egri, Lajos. 1946. The Art of Dramatic Writing. New York: Simon \& Schuster, Inc.

Garfinkel, Asher. 2007. Screenplay Story Analysis The Art and Business. New York: Allworth Press.

Gianneti, Louis. 2007. Understanding Movies. London: Laurence King Publishing.

Giannetti, Louis D. 2014. Understanding Movies. 13th. London: Pearson Education.

Grafinkel, Asher. 2007. Screenplay Story Analysis The Art and Business. New York: Allworth Press. 
Sense Vol 3 | No 2 | November 2020

KBBI, Tim Redaksi. 2008. Kamus Besar Bahasa Indonesia. Jakarta: Pusat Bahasa.

Kozloff, Sarah. 2000. Overhearing Film dialogue. Berkeley \& Los Angles California: University of California Press.

Lutters, Elizabeth. 2010. Kunci Sukses

Menulis Skenario. Jakarta:

Gramedia.

Myers, Isabel Briggs, dan Peter Briggs

Myers. 1995. GIFTS DIFFERING

Understanding Personality Types.

California: Davies-Black Publishing.

Pratista, Himawan. 2017. Memahami Film.

Yogyakarta: Montase Press.
Raco, J.R. 2010. Metode Penelitian Kualitatif Jenis, Karakteristik dan Keunggulannya. Jakarta: Grasindo.

Sugiyono. 2011. Metode Penelitian Kuantitatif Kualitatif dan $R \& D$. Bandung: Alfabeta.

Bicks, Jenny, dan Bill Condon. 2015. "Script Slug : The Greatest SHowman (2017)." Script Slug. 20 April. Diakses Desember 10, 2019. https://www.scriptslug.com/assets/up loads/scripts/the-greatest-showman2017.pdf. 